\title{
The influence of the flocculant on the process of thickening and depositing of copper ore flotation tailings
}

\author{
Maciej Gruszczyński \& Stanisław Czaban \\ Institute of Environmental Engineering, Wroctaw University of Environmental and Life Sciences, Poland \\ Robert Pratkowiecki, Zbigniew Skrzypczak \& Paweł Stefanek \\ KGHM Polska Miedź S. A., Hydrotechnical Unit, Poland
}

SUMMARY: In the mining industry both segregation and thickening of flotation tailings are usually used to obtain backfill material. The use of flocculants in the process of thickening tailings causes a change in the rheological parameters of the obtained mixture which directly affects the flow conditions and segregation of the solid phase. The paper presents the results of semi-technical tests of thickening, deposition and segregation of the copper ore flotation tailings. Thickening tests with and without flocculants were carried out. The material obtained at the underflow was deposited in prepared measuring ditches. During the experiments were monitored such parameters as the flow rate, particle size distribution of the solid phase and the density of the feed, overflow and underflow. The results of the experiment were analyzed with regard to the use of the underflow stream as a backfill material. After exceeding critical concentration of the solid phase, the movement of non-Newtonian fluid was observed in measuring ditches whose role was to simulate the spread of backfill in the post-mining void.

Keywords: backfill material, paste, segregation, thickening, non-Newtonian fluid

\section{NOTATION}

$c_{u} \quad$ coefficient of uniformity [-]

$d_{10}$ Grain size indicator, particle diameter corresponding $10 \%$ cumulative undersize particle size distribution $[\mu \mathrm{m}]$

$d_{50}$ Grain size indicator, particle diameter corresponding 50\% cumulative undersize particle size distribution $[\mu \mathrm{m}]$

$d_{60}$ Grain size indicator, particle diameter corresponding $60 \%$ cumulative undersize particle size distribution $[\mu \mathrm{m}]$

$x \quad$ Distance $[\mathrm{m}]$

$y \quad$ Elevation $[\mathrm{m}]$

$\rho \quad$ Solids density $\left[\mathrm{kg} \cdot \mathrm{m}^{-3}\right]$

\section{INTRODUCTION}

Tailings are fine-grained materials that remain after valuable metals and minerals have been extracted from ore (Lee et al. 2017). One of the most important directions of flotation tailings management - as far as the impact of the mining industry on the natural environment is concerned - is the deposit of tailings at the mine in the form of paste (Stefanek \& Serwicki, 
2014). The primary advantage of paste fill is: the fill has little or no bleed water thus simplifying mine dewatering (Fehrsen \& Cooke 2010), This technology requires the production of paste from tailings in the dewatering process ( $\mathrm{Li}$ et al. 2017) such as hydrocyclonage or filtration so as to reduce the water content (Stone 2014). We can define paste as a mixture with a reduced amount of water (Annor. 1999) which can be pumped and does not separate during flow and depositing (Belem \& Benzaazoua 2008, Theriault et al. 2003, Yilmaz et al. 2011).

In copper ore mines in Poland there is space to be filled with tailings. The estimated volume of voids in the goafs amounts to respectively: O/ZG "Lubin"- 2.2 million $\mathrm{m}^{3}$, O/ZG "Rudna"- 3.9 million $\mathrm{m}^{3}, \mathrm{O} / \mathrm{ZG}$, "Polkowice - Sieroszowice" - 1.9 million $\mathrm{m}^{3}$, the total capacity of the goafs is approximately 8 million $\mathrm{m}^{3}$ (Mazurkiewicz et al. 2015).

The technological process of producing paste requires reducing the amount of water in the tailings, which generates significant costs (Gruszczyński 2019). The paper presents the results of thickening using the thickener on a semi-technical scale. The flocculant was used in the thickening process, which may affect the geotechnical parameters of the generated underflow (ICOLD, 2001). During the conducted experiments, the obtained thickened tailings were deposited in specially prepared experimental fields so that the flow angles could be assessed.

\section{PURPOSE AND CONDUCT OF THE RESEARCH}

The aim of the study was to determine the impact of the flocculant on the course of the process of thickening, depositing and segregating of tailings (Palkovits 2011). The Mobile Thickening Unit (MTU) (Figure 1) was used for the tests. While preparing the experiments, the prototype equipment destined for the MTU was designed and built. The research was carried out for tailings from copper Ore Enrichment Plant (OEP). In view of the anticipated measurement difficulties, the MTU was located on a wheeled platform (Figure 1).

Thickening tests were carried out without and with the addition of the flocculant for 5 measurement series. The parameters of feed, underflow and overflow from the MTU were determined and the process of depositing on the Tailing Storage Facility (TSF) beach was assessed. During the tests the MTU operating parameters were monitored "on-line" using the installed equipment. Samples of the deposited underflow from the beach were collected to determine segregation as a function of distance from the discharge point. Tailings beach slope, deposition process, erosion and accumulation areas where determined using the laser scanning technique and surface numerical model. During the tests, samples of the mixture were taken and their physical properties were determined. The impact of the flocculant on the segregation process of the deposited material on the beach was indicated as well as longitudinal slopes of the deposited material. It was observed that the addition of the flocculant significantly changes the regime of tailings flow on the beach.

\section{MOBILE THICKENING UNIT}

The main element of the installation was a cone thickener DN900. The thickener had the height of $100 \mathrm{~cm}$ (Figure 2). The thickener was equipped with: feed stream confusor, rake arm, overflow weir, underflow stream diffuser. The thickener was additionally equipped with a sight glass enabling observation of the flocculation process and bed height. All the elements of the device in contact with the feed were made of stainless steel. Figure 2 presents the technological scheme of the MTU.

Due to the expected distribution of density and grain size of the solid phase in horizontal distributing pipelines, it was decided to supply the thickening station with 3 spigots of different heights. The spigots were installed on section N3 of $\Phi 800$ distributing pipeline carrying tailings of copper ore flotation from OEP. They were installed at three heights in relation to the axis of the pipeline, i.e. above the axis, in the axis and below the axis. Each spigot was equipped with a DN100 gate valve with a Perot type quick coupler. 


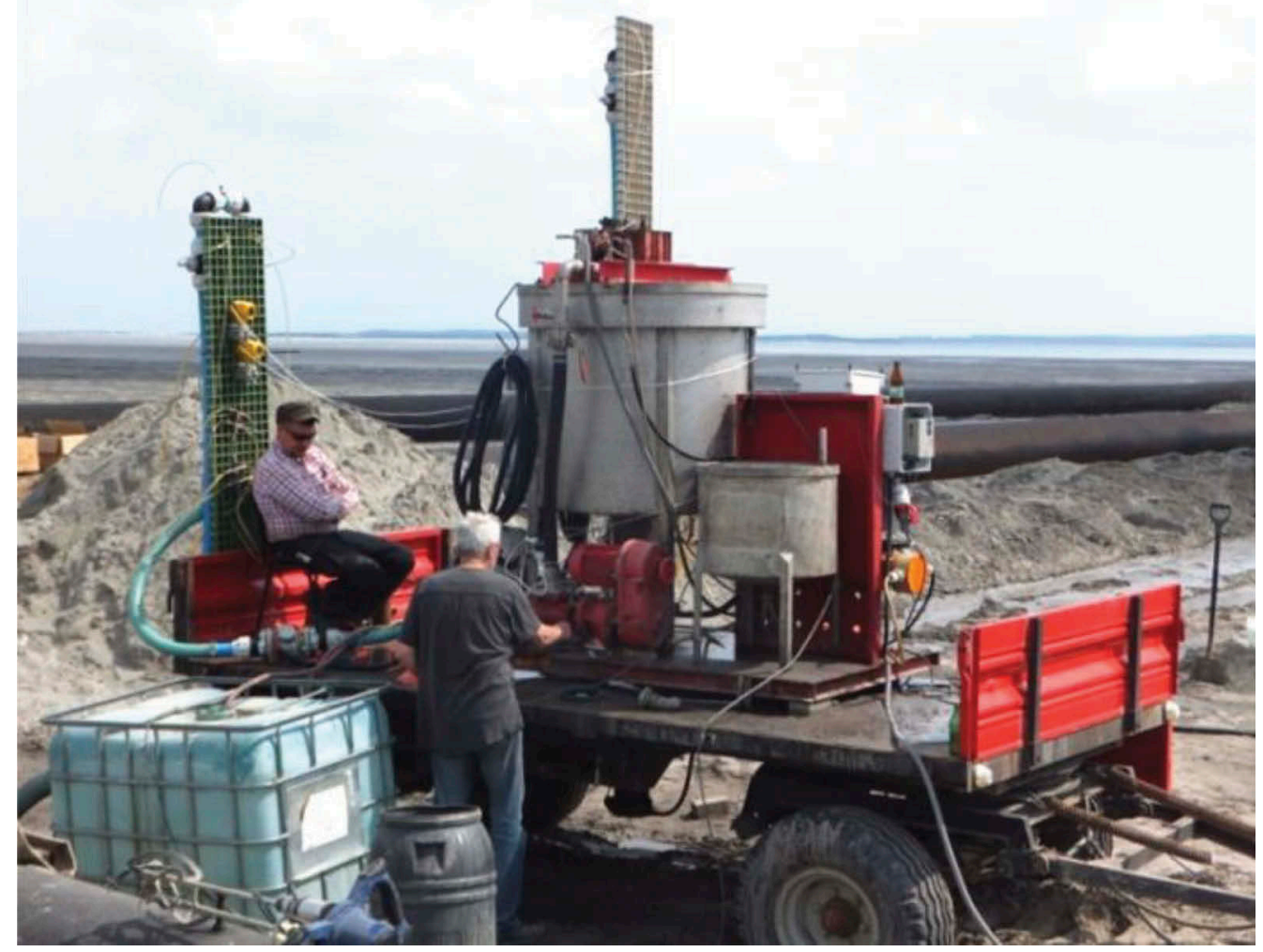

Figure 1. Mobile Thickening Unit during measurements.

Source: Own source.

The installation was equipped with two U-bend density meters. The density meters were made in the form of loops from pipes DN63 SDR17 PEHD100 (Figure 2). The density meters consisted of two measuring sections $2.27 \mathrm{~m}$ long located vertically. In both measuring sections, the medium flowed in opposite directions, i.e. up and down. Pressure differences were measured on each measuring section using an Aplisens electronic pressure transmitter. Impulse tubes supplying pressure to the measuring membrane were rinsed and fully filled with tap water. The accuracy of the pressure difference measurement was $0.1 \%$ of the full measuring range of the device, i.e. $0.025 \mathrm{kPa}$. Before testing, the density meters were checked and calibrated on fresh water for the full range of flow rate measurement, i.e. from 0 to $10 \mathrm{~m}^{3} \cdot \mathrm{h}^{-1}$. Impulse tubes were made of transparent polyurethane DN10, which allowed for ongoing assessment of patency, purity and air in the pressure difference measurement installation.

The installation was equipped with two electromagnetic flow meters dedicated to slurry flow from Techmag DN 50 and DN 32. The first flow meter was installed on the feed line, between the density meter and the supply pump and the other on the underflow line. The flow meters were equipped with an electronic display showing the current flow and the sum of the flow. The electromagnetic flow meters used were not sensitive to possible stationary bed in the measuring head cross section (Baker 2000 ).

The installations were equipped with sampling points for laboratory tests. The points were located on vertical sections of pipelines and equipped with DN 6.5 ball valves. This solution allowed the collection of the most reliable samples of tailings from three streams, i.e. from the feed, underflow and from overflow. The samples were sealed in plastic containers after collection. The secured samples were sent to the geotechnical laboratory. Particle size distribution measurements were made with a Mastersizer 2000 instrument. 


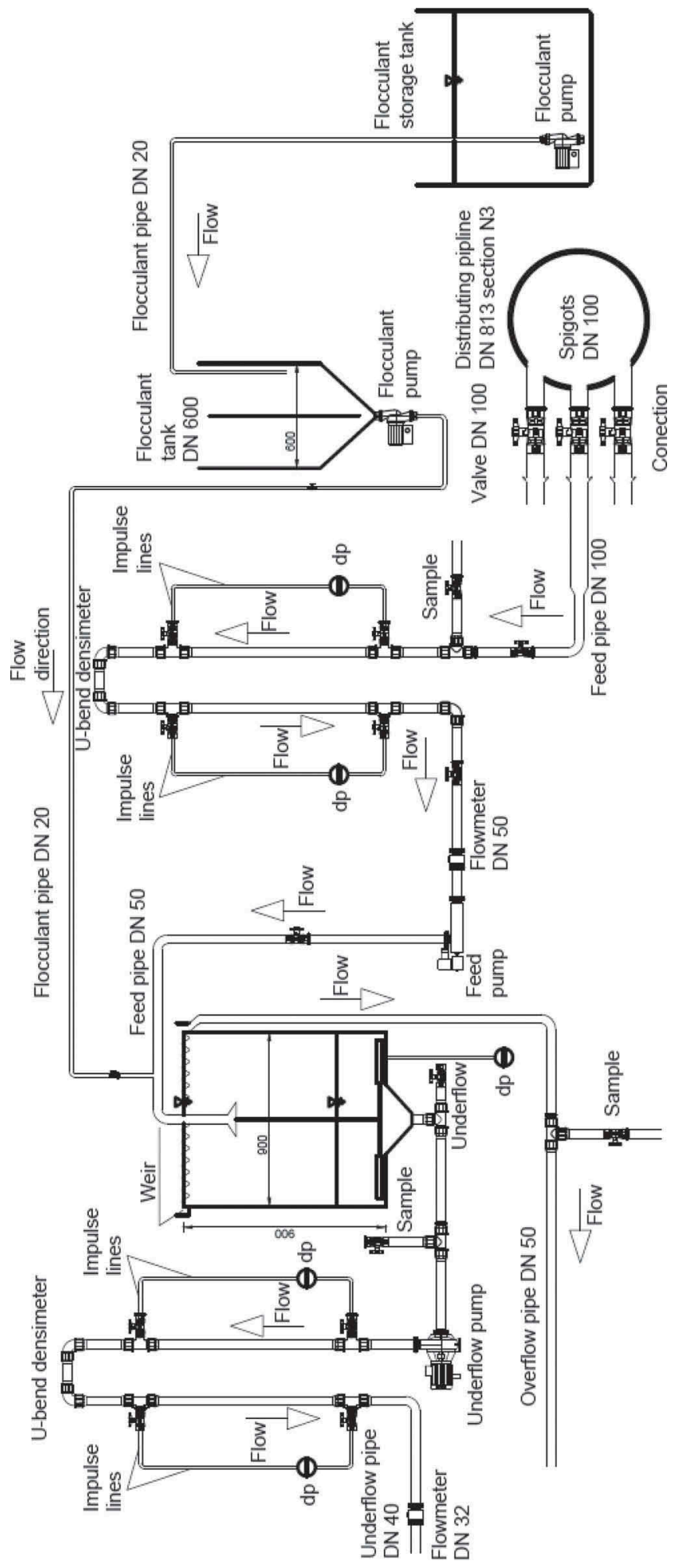

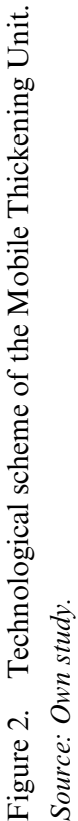


The AN 820VHM flocculant was prepared in two phases. In the first phase, the flocculant was prepared at a $1 \%$ concentration in a 100-liter plastic container. According to the manufacturer's instructions, the flocculant matured for $48 \mathrm{~h}$. Then the flocculant was diluted to a concentration of $0.1 \%$. The flocculant prepared in this way was pumped from the container to the $280 \mathrm{dm}^{3}$ flocculant tank with which the thickener was equipped. It was assumed that the initial dose of the flocculant would be $50 \mathrm{~g} \cdot \mathrm{Mg}^{-1}$ of the solid phase of the feed stream. As the actual solid phase mass flow was determined only after laboratory tests, the solid phase amount was assumed at $2.0 \mathrm{Mg} \cdot \mathrm{h}^{-1}$ on the basis of those preliminary tests. Thus the initial flocculant amount was assumed to be $100 \mathrm{~g} \cdot \mathrm{h}^{-1}$. During the tests, the flocculant dose was being increased until clean water was obtained in the overflow.

Thickened tailings were pumped to the previously prepared test stands to assess beach slope and particle size distribution along the deposited material. Seven measuring fields were prepared in the form of trapezoidal channels (ditches) from R1 to R7 (Figure 3.), $150 \mathrm{~m}$ long and $0.30 \mathrm{~m}$ wide at the bottom.

In order to assess the sedimentation processes in the prepared fields, the technique of laser scanning and mathematical modelling of the terrain surface was used. After filling the experimental ditches, laser scans of the study area were made. In order to achieve high accuracy the scanning operation was performed three times.

\section{RESULTS OF THE CONDUCTED EXPERIMENTS}

The research was carried out in difficult field conditions in the TSF. Supplying the MTU from the tailings transfer installation enabled the station to operate in conditions as close as possible to a real installation. Figure 4a shows the efficiency of individual streams entering and leaving the MTU. Figure 4b presents the measured densities of feed, underflow and overflow of the MTU.

Figures $4 \mathrm{a}$ and $4 \mathrm{~b}$ show four MTU modes. The start-up mode lasted from 13:25 to 13:50. The MTU worked without the addition of the flocculant from 13:50 to 15:10. The flocculant dosing started at 15:10 and lasted for an hour to 16:10. Turning off the MTU lasted from 16:10 to 16:40.

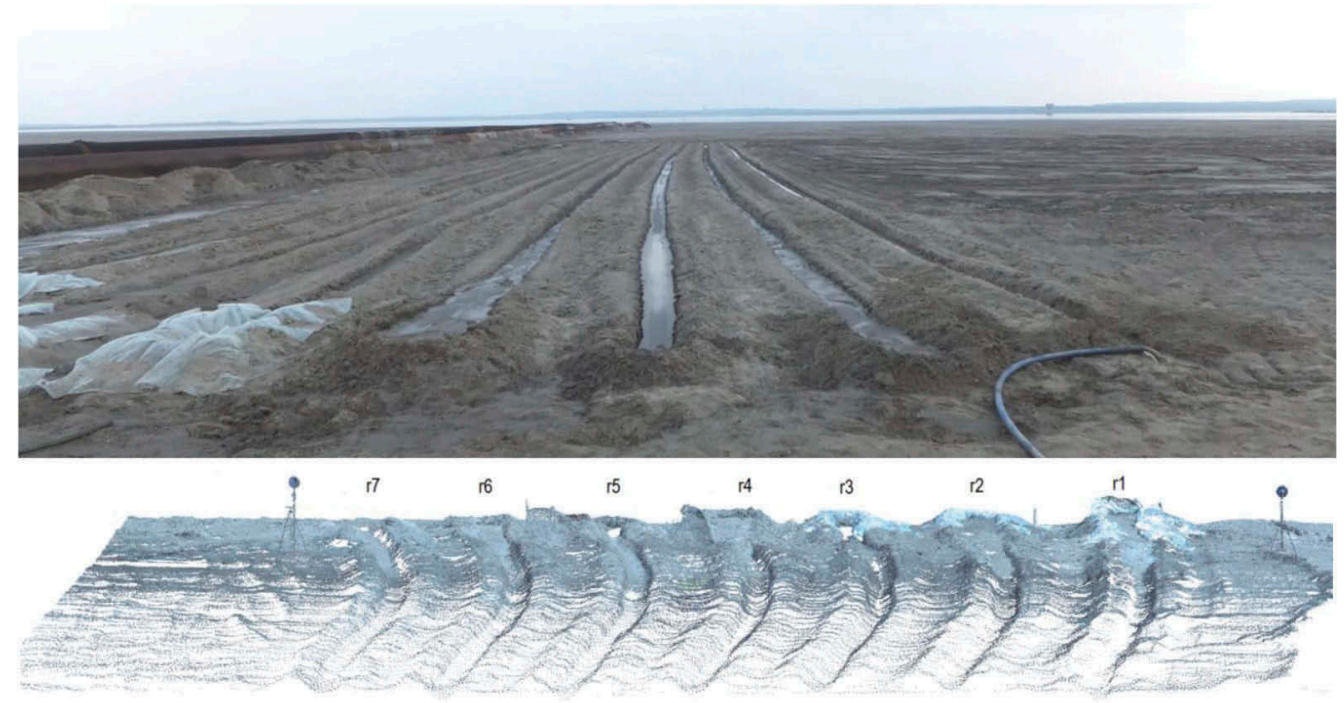

Figure 3. Photography and scan of prepared measuring channels.

Source: Own study 
a)

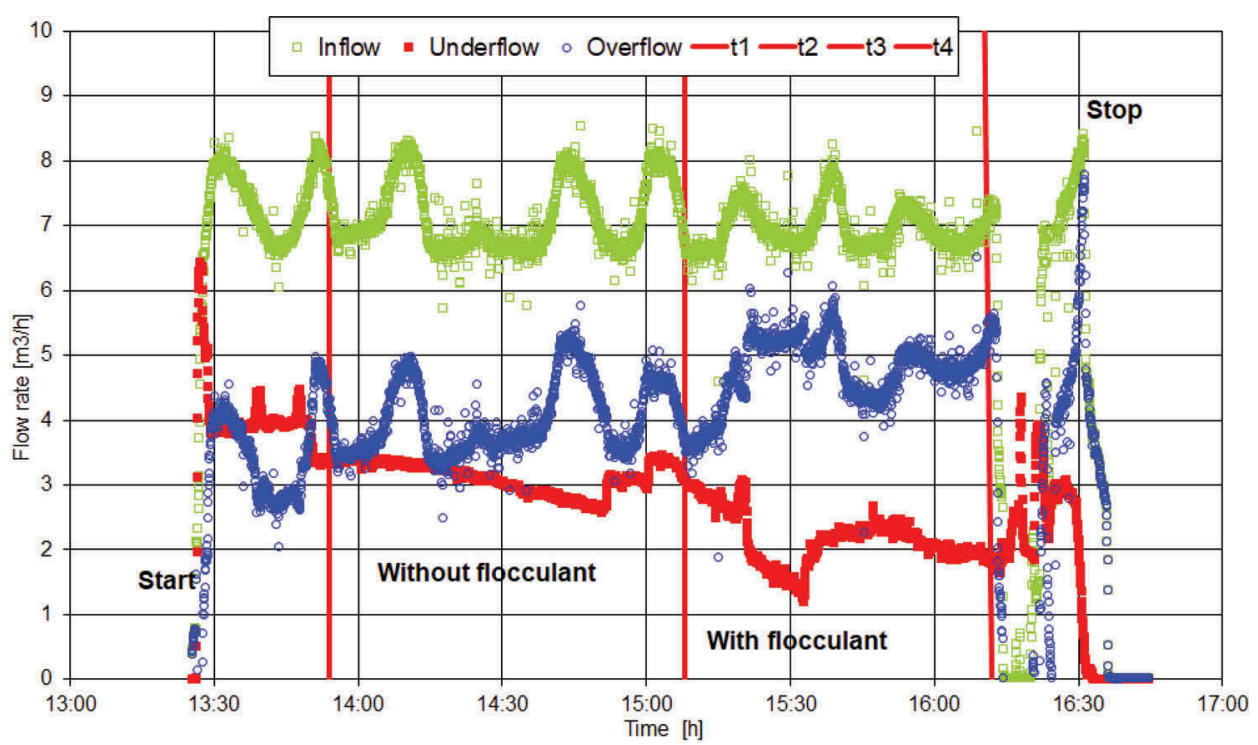

b)

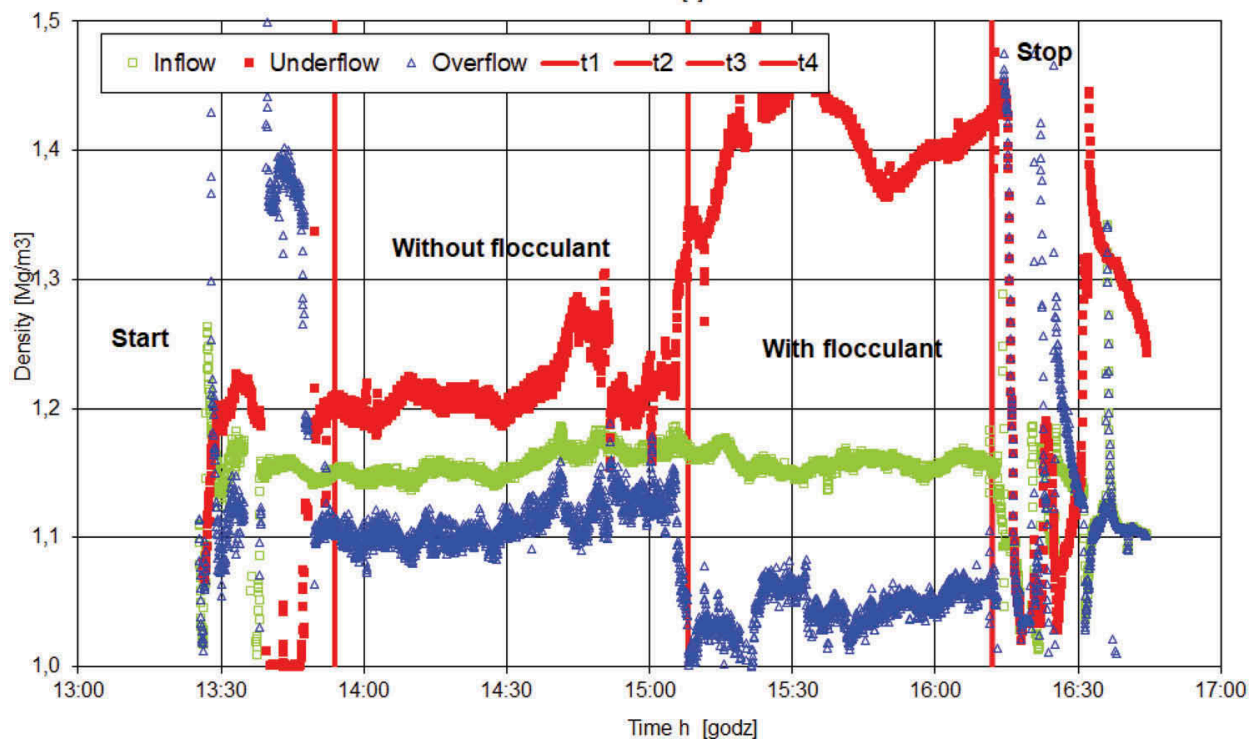

Figure 4. a) The flow- b) The density- of feed, underflow and overflow of Mobile Thickening Unit. Source: Own study.

The presented data refer to the case with the use of a flocculant dose $50 \mathrm{~g} \cdot \mathrm{Mg}^{-1}$. It can be observed that in the presented case the full purity of the overflow was not achieved.

During the tests, samples were taken from the feed stream, overflow, underflow and from the experimental ditches in which the thickened tailings were deposited. The grain size distribution of the samples taken was determined. The measurements can be divided into two groups, i.e. without flocculant and with flocculant. Figure 5a shows the particle size distributions of individual streams and tailings deposited in the experimental channels for the case of the MTU working without the flocculant. In the thickener, the coarse particles whose grain size indicator $d_{50}$ is $70 \mu \mathrm{m}$ are segregated and flow in underflow. Fine fraction with the grain size indicator $\mathrm{d}_{50} 10 \mu \mathrm{m}$ flows to overflow. Feed flow $\mathrm{d}_{50}$ was $20 \mu \mathrm{m}$ and for tailings disposited in the dich was $100 \mu \mathrm{m}$. 

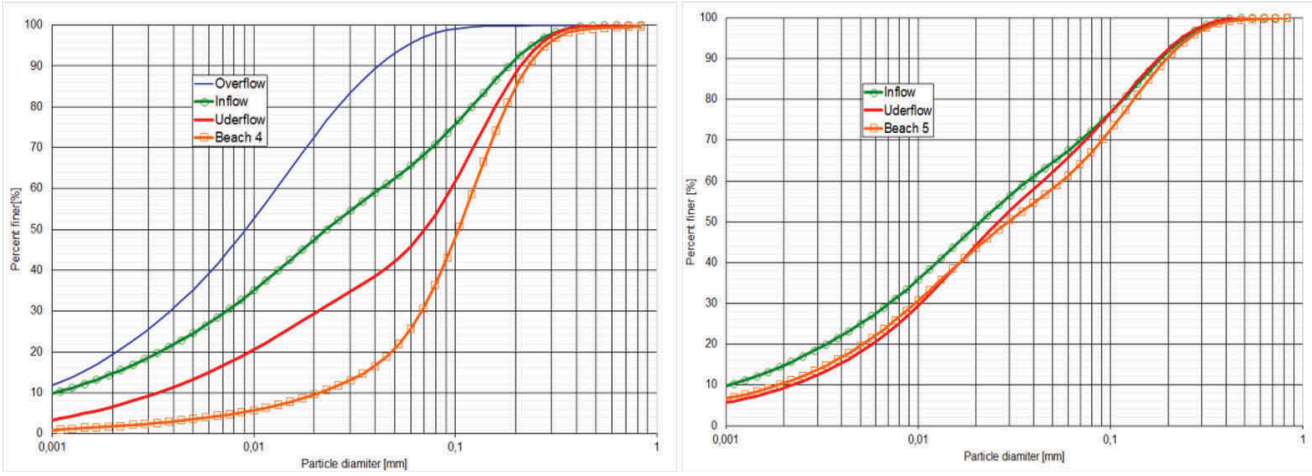

Figure 5. Average grain size composition in feed, underflow, overflow and in experimental channel; a) for the tests without flocculant; b) tests with flocculant.

Source: Own study.

Another test discussed in the work is the use of the flocculant in the process of thickening tailings in the MTU. When the MTU was operating with the flocculant, clean water was achieved in the overflow in which no solid particles were observed (Figure 5b). Grain size indicator $\mathrm{d}_{50}$ of tailings in feed, underflow and experimental channel is almost the same and amounts to $20 \mu \mathrm{m}$.

After filling the experimental channels, the slope was assessed. Before starting the experiment, the shape of the entire deposition area and of the ditches was measured using laser scanning techniques. Figure 6 presents a numerical model of the deposition area generated on the basis of laser scanner measurements. Comparison of numerical terrain models was used to determine the shape of the deposited thickened tailings.

Table 1 presents the deposited underflow length and parameters for all seven ditches. In three cases, the MTU worked without the flocculant. In four cases, the tailings going to the ditches were thickened with the addition of the flocculant. In three cases, clean water was

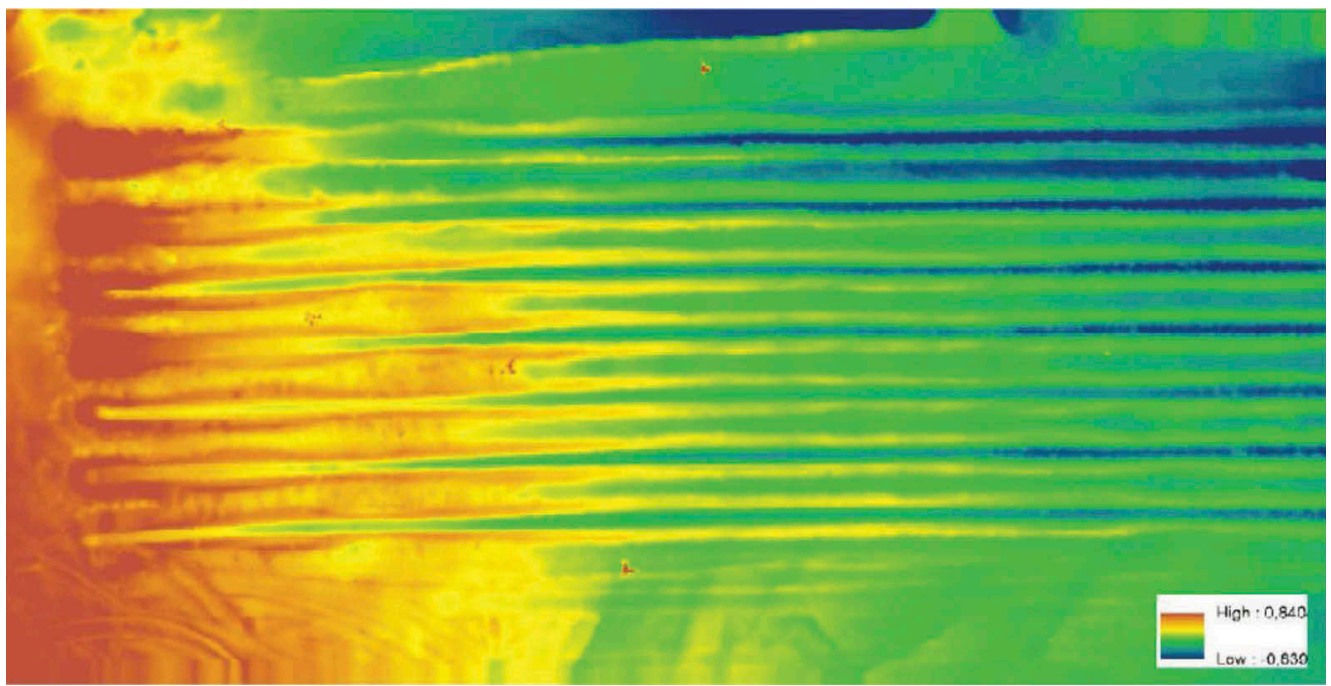

Figure 6. Numerical Terrain Model of the measuring ditch region.

Source: Own study. 
Table 1. Types of deposits in experimental ditches.

\begin{tabular}{llll}
\hline Experimental ditch & Addiction of flocculant & Overflow transparency & $\begin{array}{l}\text { Deposit length } \\
{[\mathrm{m}]}\end{array}$ \\
\hline R1 & No & No & 18 \\
R2 & Yes & No & 16 \\
R3 & Yes & Yes & 7 \\
R4 & No & No & 16 \\
R5 & Yes & Yes & 40 \\
R6 & No & No & 12 \\
R7 & Yes & Yes & 35 \\
\hline
\end{tabular}

Source: Own study

achieved on the overflow. The maximum measured length of deposited overflow was 40 meters, while the minimum length was 7 meters.

Figure 7 shows the longitudinal profile of ditches R1 to R7. Longitudinal profiles were made for all the ditches on the basis of numerical model assessment. The measurements showed the influence of distance from the discharge point on the slope of disposed material. For measuring series in which no flocculant was used, the slopes of the beach in the initial section were from 3 to $6 \%$, and with the increase in the distance they decreased to $2-3 \%$ ( R1, R4 and R6). The average slope of deposited underflow ranged from 2.6 to $3.6 \%$. For the experiments in which the flocculant was used, the slopes were much lower. At the beginning the slope was within a range of 2.4-3.5\%, and at a further distance about $1 \%$. The average slope of deposited underflow ranged from 1,1 to $3,6 \%$.

Parameter coefficient of uniformity is defined as (1):

$$
c_{u}=\frac{d_{60}}{d_{10}}
$$

Figure 8 shows the grain size indicator coefficient of uniformity $\mathrm{c}_{\mathrm{u}}$ distribution along the length of the ditches. The parameter distribution in ditches R3 R5 and R7 oscillates within the

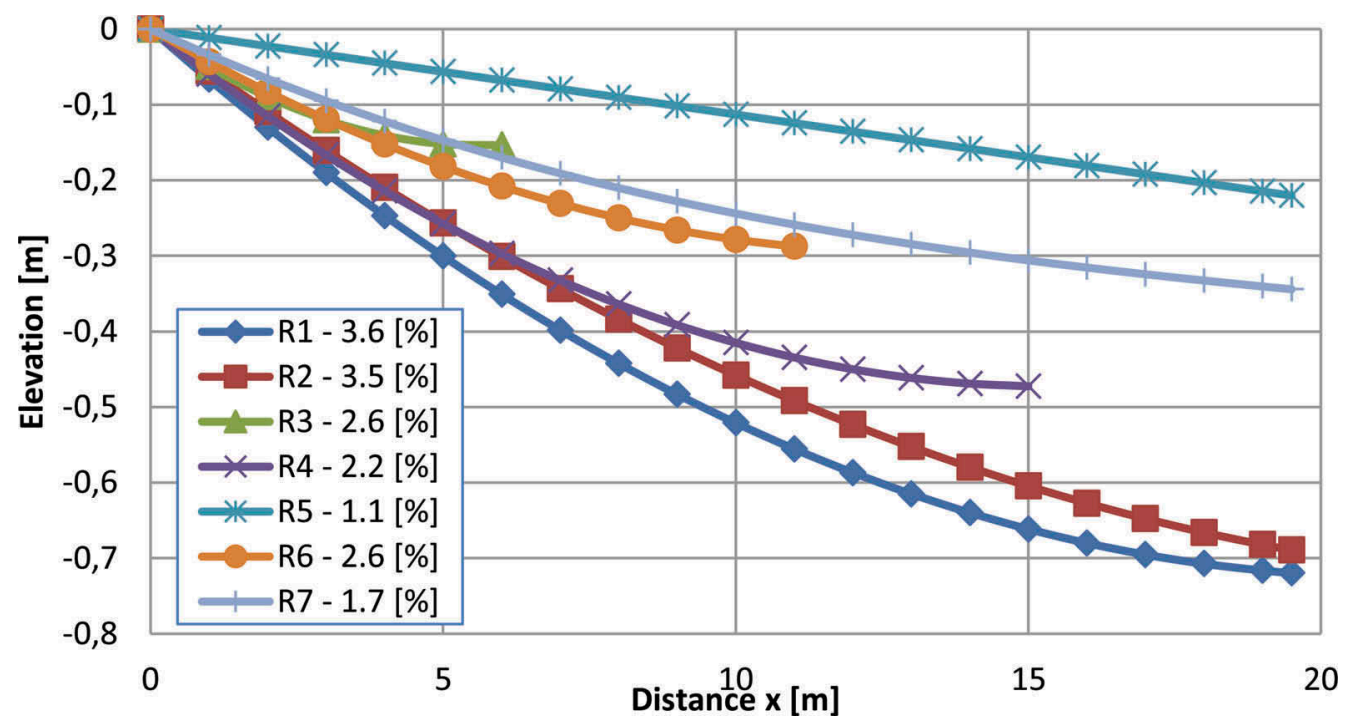

Figure 7. Slope of ditches R1 to R7.

Source: Own study. 


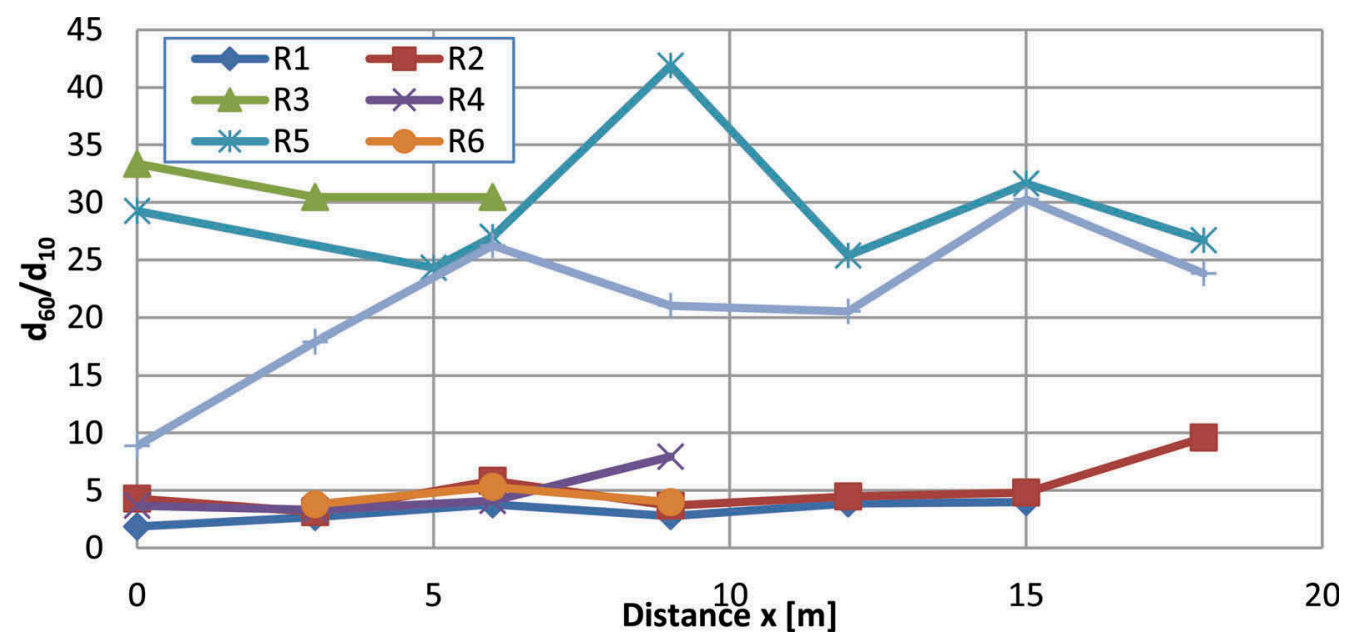

Figure 8. Dependence of the grain size indicator - coefficient of uniformity $\mathrm{d}_{60} / \mathrm{d}_{10}$ on the distance from the discharge point. Ditches R1-R7.

Source: Own study.

value of 25 . The parameter is more or less horizontally arranged. The discussed case is the use of the flocculant in a dose ensuring a clean overflow. In other cases, the parameter $\mathrm{d}_{60} / \mathrm{d}_{10}$ is almost horizontal and does not deviate from the value of 5. A strong dependence between the coefficient of uniformity $\mathrm{d}_{60} / \mathrm{d}_{10}$ and the flocculant use is observed.

\section{CONCLUSIONS}

- The proposed measurement methodology has received good practical confirmation. This applies both to the apparatus installed on the Mobile Thickening Unit and also to the depositing process evaluation,

- Underflow from the thickener with the flocculent applied can be used as a material for the preparation of backfill paste or for sealing goafs,

- As a result of the observation of the process of depositing tailings with the flocculant applied, it was found that the tested slurry, in almost the entire length, flows with the movable bottom sediment regime. The basic type of particle displacement on the beach is slow dragging and rolling. The suspended fine particles are dust and clay fraction. Studies have shown that in the place where the mixture stream falls on the layers of embedded soil, erosion funnel is formed,

- The depositing process for which the flocculant was used in the MTU was different. The slurry with the flocculant moved homogeneously and not heterogeneously,

- For the experiments in which the flocculant was used, the tailings deposited on the beach were practically not segregated, whatever the distance from the place of discharge, there was no reduction in granulation or reduction of the sand fraction content,

- Macroscopic observations have shown that the deposited material with the flocculant has greater porosity. Dewatering process occurs much more slowly. This may mean the possibility of liquefying deposited tailings under the influence of rockburst as well as much larger volumes of water retained compared to the current state. 


\section{BIBLIOGRAPHY}

Annor, A. B. 1999. A Study of the Cbaracteristics and Behaviour of Composite Bacldill Material, McGill University Department of Mining and Metallurgical Engineering, Thesis for degree of Doctor of Philosophy.

Baker, R. C. 2000 Flow Measurment Handbook, Cambridge University Press.

Belem, T. and Benzaazoua, M. 2008. Design and application of underground mine paste backfill technology, Geotechnical and Geological Engineering., vol. 26, no. 2, pp. 147-174.

Fehrsen, M. and Cooke R. 2010. Paste fill pipeline distribution systems - current status, pp. 1-13.

Gruszczyński, M. 2019. The assessment of the impact of the rheological parameters of fine-grained copper ore flotation tailings on friction head losses in pressure pipes. Wrocław University of Environmental and Life Sciences

ICOLD, 2001. Tailing Dams risk of dangerous occurrences, International Commission on Large Dams, vol. XXXIII, no. 2, p. 144.

Lee et al. 2017 - Lee, J. K., Ko, J. and Kim, Y. S. Rheology of Fly Ash Mixed Tailings Slurries and Applicability of Prediction Models, vol. 7, no. 9, p. 165.

Li et al. 2017 - Li, H., Zhang, J., Zhang, D, Li, Z and Hu, G. Paste pipeline transportation for Chambishi Copper Mine, [in:] A Wu \& R Jewell (eds), Proceedings of the 20th International Seminar on Paste and Thickened Tailings, University of Science and Technology Beijing, Beijing, pp. 393-401, https://doi. org/10.36487/ACG_rep/1752_44_Li

Mazurkiewicz et al. 2015 - Mazurkiewicz, M., Popiołek, E., Niedojadło, Z., Sopata, P. and Stoch, T. Some Aspects Of Using Goafs For Locating Post-Flotation Waste In LGOM Mines, Archives of Mining Sciences, vol. 60, no. 4, pp. 941-954.

Palkovits, F. 2011. Paste Thickening: Considerations for Backfill vs. Tailings Management, Engineering and Mining Journal. no. November, pp. 3440

Stefanek, P. and Serwicki, A. 2014. Ograniczenie oddzialywania OUOW Żelazny Most na środowisko poprzez zmianę technologii składowania odpadów, Warsztaty 2014 z cyklu Górnictwo - człowiek - środowisko zrównoważony rozwój, pp. 394-406.

Stone. D. 2014. The evolution of paste for backfill, pp. 31-38, 2014

Theriault et al. 2003 - Theriault, J. A., Frostiak, J., Welch, D. and Corporation, B. G. Surface Disposal of Past Tailings at the Bulyanhulu Gold Mine, Tanzania, Mining Environmental III Conf., pp. 1-8.

Yilmaz et al. 2011 - Yilmaz, E., Belem, T., Benzaazoua, M., Kesimal, A., Ercikdi, B. and Cihangir, F. Use of high-density paste bacfill for safe disposal of copper/zinc mine tailings, Gospodarka Surowcami Mineralnymi, vol. T. 27, z., pp. 81-94. 